\title{
Media Animasi Menggunakan Macromedia Flash Berbasis Pemahaman Konsep Pokok Bahasan Persegi dan Persegi Panjang
}

\author{
Dita Andini ${ }^{1}$, Nanang Supriadi ${ }^{1}$ \\ 1 Universitas Islam Negeri Raden Intan Lampung. Jalan Endro Suratmin, Sukarame, Bandar \\ Lampung 35133, Indonesia. \\ *Corresponding Author. E-mail: dita.andini52@yahoo.com
}

Received : 13-02-2018; Revised : 08-05-2018; Accepted : 30-05-2018

\begin{abstract}
Abstrak
Penelitian ini bertujuan untuk mengembangkan media animasi menggunakan macromedia flash berbasis pemahaman konsep pokok bahasan persegi dan persegi panjang. Adapun metode penelitian dan pengembangan yang digunakan adalah model 4D yang dikemukakan oleh Thiagarajan yang terdiri dari 4 tahapan yaitu: (1) define atau pendefinisian; (2) design atau perancangan; (3) develop atau pengembangan dan (4) disseminate atau penyebaran. Peneliti menggunakan teknik pengumpulan data yaitu angket (kuisioner) berupa skala Likert untuk respon peserta didik. Hasil penelitian adalah media animasi menggunakan macromedia flash berbasis pemahaman konsep pokok bahasan persegi dan persegi panjang yang layak digunakan sebagai media pembelajaran. Kelayakan media pembelajaran diperoleh dari hasil validasi ahli materi dengan rata-rata skor 3,40 yang berkategori valid dan validasi ahli media dengan rata-rata skor 3,32 yang berkategori valid. Respon peserta didik terhadap media pembelajaran yang diperoleh pada uji kelompok kecil yaitu sangat menarik dengan skor ratarata sebesar 3,64. Pada uji kelompok besar diperoleh kriteria kemenarikan yaitu sangat menarik dengan skor rata-rata sebesar 3,47.
\end{abstract}

Kata Kunci : Macromedia Flash, Pengembangan Media, Pemahaman Konsep.

\begin{abstract}
This study aims to develop animation media using Macromedia flash based on the conceptual understanding of the subject of rectangle and rectangle. The research and development method used is $4 D$ model proposed by Thiagarajan consisting of 4 stages, namely: (1) define; (2) design; (3) develop and (4) disseminate. Researchers use data collection techniques is a questionnaire in the form of Likert scale for the response of learners. The result of the research is the animation media using Macromedia flash based on the concept of the subject of rectangular and rectangle that is suitable for learning media. The feasibility of learning media obtained from the validation of material experts with an average score of 3.40 is categorized valid and validation of media experts with an average score of 3.32 are categorized as valid. Student response to learning media obtained in small group test is very interesting with an average score of 3.64. In the large group, test obtained criteria attractiveness is very interesting with an average score of 3.47.
\end{abstract}

Keywords: Macromedia Flash, Media Development, Understanding Concepts.

\section{PENDAHULUAN}

Pendidikan merupakan kebutuhan mutlak yang harus dikembangkan sejalan dengan tuntunan pembangunan secara tahap demi tahap. Pendidikan juga tidak bebas dari pengaruh teknologi. Hasil teknologi sudah lama dimanfaatkan dalam bidang pendidikan. Contohnya kertas, mesin cetak, radio, film, TV, komputer dan lain-lain dimanfaatkan di bidang pendidikan. Dengan alat-alat itu dapat mengubah pikiran manusia, mengubah cara kerja dan cara hidupnya. Alat bantu adalah benda yang dapat mewakili suatu gagasan. Saat otak mengingat informasi, biasanya dilakukan dalam bentuk gambar warna-warni, 
simbol, bunyi, dan perasaan (Porter, D, \& Dkk, 2010). Alat-alat teknologi pendidikan dapat mengubah peranan guru. Dalam menyampaikan pelajaran banyak alat telah diciptakan agar mempermudah peserta didik untuk memahaminya. Penggunaan media pada kegiatan pembelajaran bertujuan untuk mempermudah guru dalam menyampaikan materi. Mengajar pada umumnya usaha guru untuk menciptakan kondisi-kondisi atau mengatur lingkungan sedemikian rupa, terjadi interaksi antara peserta didik dengan lingkungan, guru, alat pelajaran, dan sebagainya yang disebut proses belajar, sehingga tercapai tujuan pelajaran yang telah ditentukan. Dalam kegiatan pembelajaran, media merupakan salah satu sumber belajar yang dapat menyampaikan pesan-pesan pendidikan kepada para peserta didik. Perbedaan gaya belajar, minat, intelegensi, keterbatasan indera, hambatan jarak dan waktu dan lain-lain dapat dibantu dengan memanfaatkan media (Farida, 2015). Pada masa kini komputer telah memberikan pengaruh yang sangat kuat terhadap pembelajaran. Alat-alat tersebut menawarkan kemungkinan untuk menjadi lebih baik dalam proses belajar mengajar. Media pembelajaran mempunyai fungsi yang sangat penting dalam proses belajar mengajar untuk meningkatkan mutu pendidikan (Sari, Farida, \& Syazali, 2016).

Pembelajaran menggunakan media komputer dapat merangsang siswa untuk mengerjakan latihan, melakukan kegiatan simulasi karena tersedianya animasi grafik, warna, dan musik. Komputer juga dapat mengakomodasi peserta didik yang lamban dalam menerima pelajaran karena dapat mempengaruhi karakteristik afektif peserta didik, sehingga peserta didik tidak mudah lupa dan tidak mudah bosan. Karena penggunaan media pembelajaran lebih efektif dan praktis dalam pembelajaran (Khuzaini, 2014). Sebagai contoh, jika guru ingin mengajarkan konsep persegi, maka guru disarankan menyajikan beberapa gambar persegi dengan ukuran sisi berlainan. Dengan demikian, sajian berupa media pembelajaran memberi pengaruh terhadap peningkatan pemahaman peserta didik terhadap konsep-konsep matematika. Karena pemahaman konsep matematis menentukan keberhasilan belajar matematika peserta didik (Purwanti, Pratiwi, \& Rinaldi, 2016).

Melakukan inovasi terbaru dalam belajar-mengajar yaitu digunakannya media pembelajaran yang tepat bisa saja mengatasi maslah yang sering terjadi (Sumiyati, Netriwati, \& Rakhmawati, 2018). Media pembelajaran yang mampu memberikan visualisasi secara jelas tentang kejadian-kejadian yang terkait dengan mata pelajaran tersebut yang sesuai konsep persegi dan persegi panjang akan membuat peserta didik lebih tertarik dengan matematika serta dapat memudahkan peserta didik dalam memahami konsep-konsep matematika. Banyak peserta didik sangat suka animasi, menggambar anime dan membaca buku bergambar seperti komik, Jadi dengan adanya media pembelajaran dengan animasi peserta didik akan lebih suka dan lebih mengerti sehingga berguna untuk memperjelas penyajian materi, mengatasi keterbatasan ruang, dapat mengatasi peserta didik bersifat pasif, menimbulkan kegairahan pada peserta didik, memberikan perangsangan dan persepsi yang sama dan memungkinkan peserta didik belajar sendiri-sendiri menurut kemampuan dan minatnya. Visualisasi yang ditampilkan secara menarik, dapat digerakkan dan diubah bentuk serta ukurannya, memberi kesempatan kepada siswa untuk melakukan eksplorasi dan observasi dengan mudah (Supriadi, 2015). 
Media animasi menggunakan macromedia flash berbasis pemahaman konsep pokok bahasan persegi dan persegi panjang adalah media pembelajaran berupa media animasi yang didalamnya berisi materi persegi dan persegi panjang yang kemudian dikemas dengan konsep-konsep secara menarik. Melalui media animasi menggunakan macromedia flash berbasis pemahaman konsep ini juga diharapkan agar peserta didik akan lebih bersemangat, tidak bosan dan tidak jenuh dalam mengikuti proses pembelajaran. Oleh karena itu materi pelajaran yang selama ini bersifat abstrak, sekarang dapat divisualisasikan sehingga lebih mudah dipahami dengan media animasi. Melalui media ini peserta didik tidak hanya mendengar penjelasan dari guru saja, peserta didik juga dapat melihat materi yang disampaikan dalam bentuk animasi yang dibuat semenarik mungkin.

Penggunaan media animasi menggunakan macromedia flash berbasis pemahaman konsep pokok bahasan persegi dan persegi panjang juga pernah dilakukan oleh peneliti sebelumnya yaitu diantaranya Syariful Fahmi perbedaan dalam penelitian adalah penelitian ini menggunakan pendekatan kontekstual untuk keefektifan terhadap sikap peserta didik namun dalam penelitian penulis menggunakan pemahaman konsep dalam media (Fahmi, 2014). Penelitian lain dilakukan oleh Yunika Lestaria Ningsih perbedaan dalam penelitian adalah menggunakan lembar aktivitas mahasiswa (LAM) namun dalam penelitian penulis menggunakan macromedia flash (Ningsih, 2016). Kemudian peneliti selanjutnya yaitu Nanang Khuzaini perbedaan dalam penelitian adalah penelitian ini menggunakan Adobe Flash CS3 namun penelitian penulis menggunakan macromedia flash(Khuzaini, 2014).
Berdasarkan penelitian terdahulu yang relevan tersebut terdapat perbedaan dari setiap penelitian yang dilakukan media menggunakan macromedia flash untuk keefektifan terhadap sikap peserta didik yang dikembangkan mendapatkan kriteria pencapaian yang menarik dan layak digunakan. Sedangkan penelitian yang dilakukan penulis menggunakan media animasi menggunakan macromedia flash berbasis pemahaman konsep pokok bahasan persegi dan persegi panjang. Tujuan dari penelitian ini adalah untuk mengetahui media animasi menggunakan macromedia flash berbasis pemahaman konsep peserta didik pokok bahasan persegi dan persegi panjang yang layak dan menarik.

\section{METODE}

Jenis penelitian ini adalah penelitian dan pengembangan $(R \& D)$. $R \& D$ merupakan metode penelitian yang digunakan untuk menghasilkan produk tertentu, dan menguji keefektifan produk tersebut (Sugiyono, 2014). Produk yang dikembangkan adalah media animasi menggunakan macromedia flash. Penelitian pengembangan ini merujuk pada model pengembangan Thiagarajan yang terdiri atas empat tahapan, yakni tahap (1) pendefinisian (define), (2) perancangan (design), (3) pengembangan (develop), dan (4) penyebaran (dissemination) (Trianto, 2004). Penelitian ini dilaksanakan pada tanggal 25-28 november 2017 di SMP IT Bustanul U'lum Lampung Tengah. Pengujian produk ini dilakukan kepada 12 peserta didik untuk sekala kecil dan 30 peserta didik sekala besar yang diambil dalam satu kelas sekaligus melakukan uji coba pemahaman konsep.

Penelitian ini dimulai dengan tahap pendefinisian (define). Tahap ini merupakan tahap pertama atau tahap persiapan untuk pengembangan. Tahap ini bertujuan untuk menghimpun 
informasi tentang permasalahan dasar yang terjadi pada pembelajaran matematika dan kebutuhan pembelajaran, informasi tentang proses pembelajaran, dan perangkat pembelajaran yang digunakan oleh guru. Pada tahap ini dilakukan prasurvei diperoleh informasi bahwa dalam proses belajar guru belum menggunakan media pembelajaran pada materi persegi dan persegi panjang. Selain itu, nilai siswa untuk materi ini cenderung kurang.

Selanjutnya, pada tahap perancangan (desain) direncanakan suatu draf yang akan menghasilkan media animasi menggunakan macromedia flash berbasis pemahaman konsep. Dalam tahap perancangan ini ada empat langkah, yaitu penyusunan tes, pemilihan media, pemilihan format, dan rancangan awal.

$$
\text { Pada tahap pengembangan }
$$
(develop), dilakukan pengembangan media animasi menggunakan macromedia flash berbasis pemahaman konsep pokok bahasan persegi dan persegi panjang berdasarkan draf yang telah dibuat pada tahap sebelumnya. Setelah draf selesai dibuat, selanjutnya dilakukan tahap uji validasi kepada ahli materi dan ahli media. Hasil pada tahap ini adalah media animasi menggunakan macromedia flash

Tahap Uji Coba terdiri atas uji coba ahli. Uji coba ahli dimaksudkan untuk mengetahui tingkat kevalidan media animasi menggunakan macromedia flash berbasis pemahaman konsep yang dikembangkan. Data kualitatif diperoleh dari penilaian para ahli mengenai kelayakan instrumen, data validasi ahli materi, ahli media, dan respon peserta didik.

Setelah memperoleh skor dari validator, selanjutnya dilakukan pengkategorian terhadap instrumen penelitian. Apabila instrumen yang dihasilkan termasuk dalam kategori minimal valid maka instrumen dapat digunakan untuk melakukan penelitian. Namun jika penilaian dari validator belum mencapai dalam kategori minimal valid, maka dilakukan perbaikan terhadap instrumen sampai mencapai kategori minimal valid.

Tahap terakhir pada penelitian ini adalah Tahap penyebaran (dissemination). Tahap diseminasi dilakukan untuk mempromosikan produk pengembangan agar bisa diterima pengguna, baik individu, suatu kelompok atau sistem.

\section{HASIL DAN PEMBAHASAN}

Hasil penelitian ini adalah sebuah media animasi menggunakan macromedia flash berbasis pemahaman konsep pokok bahsan persegi dan persegi panjang. Tahapan yang digunakan dalam penelitian dan pengembangan ini adalah metode penelitian dan pengembangan 4D. Tahapan-tahapannya yaitu:

Tahap Pendefinisian (Define) Pada tahap ini diperoleh informasi bahwa dalam proses belajar guru jarang sekali menggunakan media pembelajaran . media yang digunakan hanya penampilan PowerPoint saja, terkhusus untuk materi persegi dan persegi panjang guru belum menggunakan media pembelajaran.

Selanjutnya tahap Perancangan (design), Media yang akan dikembangkan yaitu media animasi menggunakan macromedia flash berbasis pemahaman konsep pokok bahasan persegi dan persegi panjang. Dalam tahap perancangan ini ada empat langkah meliputi penyusunan tes patokan awal berupa persiapan angket, pemilihan media, pemilihan format, rancangan awal.

Tahap Pengembangan (develop), Pada tahap ini media dibuat dengan menggunakan aplikasi Macromedia Flash 8. 


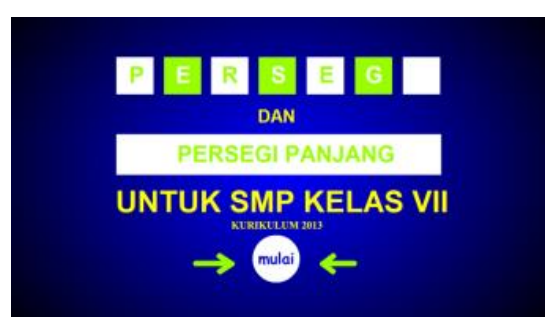

Gambar 1. Tampilan Awal Media

Setelah media di buat kemudian dilakukan penilaian oleh para ahli materi dan media untuk melihat kelayakan media yang dikembangkan.

Tabel 2 Hasil Rata-Rata Skor Validasi Ahli Materi Tahap 1

\begin{tabular}{ccc}
\hline Rata-Rata Skor & Kriteria & Keterangan \\
2,52 & Cukup & Revisi Sebagian \\
& Valid & \\
\hline
\end{tabular}

Uji coba media diawali dengan tahap validasi ahli materi. Media dinilai dari tiga aspek, yaitu: kelayakan isi, kebahasaan, dan kelayakan penyajian, secara ringkas akan dipaparkan pada Tabel 2. Berdasarkan hasil validasi media yang disajikan pada Tabel 2, terlihat bahwa media berada pada kategori Cukup Valid dan Revisi Sebagian.

Tabel 3 Hasil Rata-Rata Skor Validasi Ahli Materi Tahap 2

\begin{tabular}{ccc}
\hline Rata-Rata Skor & Kriteria & Keterangan \\
3,40 & Valid & Tanpa Revisi \\
\hline
\end{tabular}

Setelah melakukan revisi yang sesuai dengan saran para ahli. Berdasarkan hasil validasi media yang disajikan pada Tabel 3, terlihat bahwa media berada pada kategori valid dan tanpa revisi.

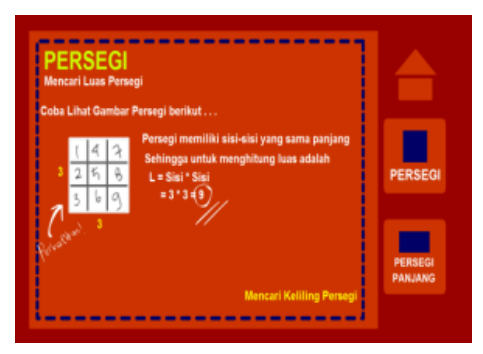

Gambar 2. Sebelum perbaikan materi

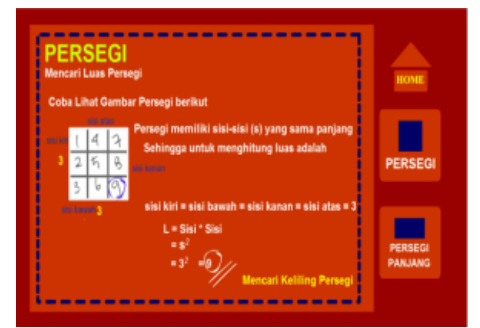

Gambar 3. Sesudah Perbaikan materi

Alasan revisi pada Gambar 2 adalah, karena untuk memperjelas maksud dari pemahaman konsep tentang luas persegi.

Tabel 4 Hasil Rata-Rata Skor Validasi Ahli Media Tahap 1

\begin{tabular}{ccc}
\hline Rata-Rata Skor & Kriteria & Keterangan \\
& Cukup & Revisi \\
3,19 & Valid & Sebagian \\
\hline
\end{tabular}

Selanjutnya validasi ahli media, media dinilai dari dua aspek, yaitu: tampilan media dan penggunaan, secara ringkas akan dipaparkan pada Tabel 4 . Berdasarkan hasil validasi media yang disajikan pada Tabel 4, terlihat bahwa media berada pada kategori cukup valid dan revisi sebagian.

Tabel 5 Hasil Rata-Rata Skor Validasi Ahli Media Tahap 2

\begin{tabular}{ccc}
\hline Rata-Rata Skor & Kriteria & Keterangan \\
3,32 & Valid & Tanpa Revisi \\
\hline
\end{tabular}

Setelah melakukan revisi yang
sesuai dengan saran para ahli.
Berdasarkan hasil validasi media yang
disajikan pada Tabel 5, terlihat bahwa
media berada pada kategori valid dan
tanpa revisi.




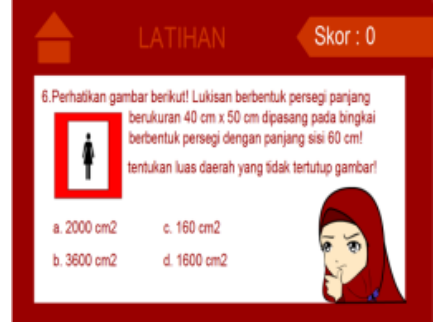

Gambar 4. Sebelum Perbaikan latihan soal

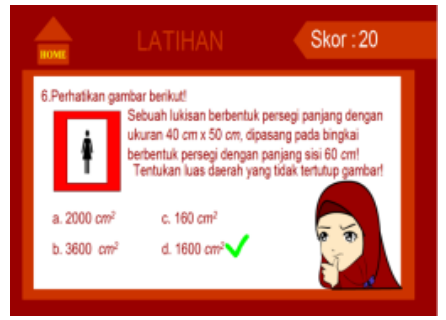

Gambar 5. Sesudah Perbaikan latihan soal

Alasan revisi pada Gambar 4 adalah agar memperjelas secara visual apakah soal yang dikerjakan benar atau salah. Kelayakan dan kevalidan produk tidak terlepas dari masukan dan saran para ahli. Perbaikanperbaikan yang dikembangkan berpedoman pada masukan-masukan serta saran yang diberikan oleh para ahli. Selanjutya uji coba produk dilakukan dalam dua tahap yaitu uji kelompok kecil dan uji kelompok besar. Hasil uji coba lapangan sebagai berikut:

Tabel 4 Hasil Rata-Rata Angket Respo Peserta Didik

\begin{tabular}{ccc}
\hline \multicolumn{2}{c}{ Skor Rata-rata } & Kriteria \\
Skala Kecil & 3,64 & Sangat Menarik \\
Skala Besar & 3,47 & Sangat Menarik \\
\hline
\end{tabular}

Pada uji coba skala kecil media media animasi menggunakan macromedia flash berbasis pemahaman konsep pokok bahasan persegi dan persegi panjang memperoleh respon peserta didik dengan kriteria sangat menarik dan skor ratarata 3,64. Pada skala besar media ini memperoleh respon peserta didik dengan kriteria sangat menarik dan rata-rata skor sebesar 3,47. Dalam hal ini dapat disimpulkan bahwa media pembelajaran ini sangat menarik untuk digunakan. Sehingga dapat dikatakan media animasi menggunakan macromedia flash berbasis pemahaman konsep pokok bahasan persegi dan persegi panjang layak digunakan dan menarik.

Tahap terakhir yaitu tahap penyebaran (disseminate), Sebelum tahap ini dilakukan terdapat revisi produk yang dilakukan apabila terdapat kendala yang ditemukan pada saat uji coba produk. Akan tetapi pada penelitian ini tidak ditemukan kendala pada uji coba produk sehingga tidak perlu ada revisi kembali.

\section{SIMPULAN DAN SARAN}

Media animasi menggunakan macromedia flash layak digunakan dengan nilai rata-rata dari ahli materi sebesar 3,40 dan nilai rata-rata dari ahli media sebesar 3,32. Selain itu respon peserta didik yang dilakukan sebanyak dua kali yaitu uji kelompok kecil dan uji kelompok besar masuk pada kategori sangat menarik dengan rata-rata skor pada uji kelompok kecil sebesar 3,64 dan uji kelompok besar sebesar 3,47. Jadi dapat disimpulkan bahwa media animasi menggunakan macromedia flash berbasis pemahaman konsep pokok bahasan persegi dan persegi panjang layak digunakan.

Saran yang dapat diberikan untuk media animasi menggunakan macromedia flash berbasis pemahaman konsep pokok bahasan persegi dan persegi panjang yaitu: penelitian ini diharapkan dapat diuji cobakan pada subjek penelitian yang berbeda sehingga dapat mengetahui lebih luas pemahaman konsep peserta didik. Serta dapat dikembangkan sehingga menghasilkan media pembelajaran yang lebih baik lagi untuk meningkatkan pemahaman konsep peserta didik sehingga membuat motivasi dan minat siswa bertambah dalam pembelajaran matematika.

\section{DAFTAR PUSTAKA}

Fahmi, S. (2014). Pengembangan Multimedia Macromedia Flash Dengan Pendekatan Kontekstual Dan Keefektifannya Terhadap Sikap 
Siswa Pada Matematika. Jurnal AgriSains, 5(2), 166-191.

Farida. (2015). Mengembangkan Kemampuan Pemahaman Konsep Peserta Didik Melalui Pembelajaran Berbasis VCD. Al-Jabar: Jurnal Pendidikan Matematika, 6(1), 25-32.

Khuzaini, N. (2014). Pengembangan Multimedia Pembelajaran Menggunakan ADOBE FLASH CS3 Untuk Pembelajaran Matematika Siswa SMA Kelas X Semester II materi Pokok Trigonometri. Jurnal AgriSains, 5(2), 192-209.

Ningsih, Y. L. (2016). Kemampuan Pemahaman Konsep Matematika Mahasiswa Melalui Penerapan Lembar Aktivitas Mahasiswa (LAM) Berbasis Teori APOS Pada Materi Turunan. Edumatica, 6(April), 1-8.

Porter, D, B., \& Dkk. (2010). Quantum Teaching. Bandung: Kaifa.

Purwanti, R. D., Pratiwi, D. D., \& Rinaldi, A. (2016). Pengaruh Pembelajaran Berbatuan Geogebra terhadap Pemahaman Konsep Matematis ditinjau dari Gaya Kognitif. Al-Jabar: Jurnal Pendidikan Matematika, 7(1),
115-122.

Sari, F. komala, Farida, \& Syazali, M. (2016). Pengembangan Media Pembelajaran (Modul) berbantuan Geogebra Pokok Bahasan Turunan. Al-Jabar: Jurnal Pendidikan Matematika, 7(2), 135-151.

Sugiyono. (2014). Metode Penelitian pendidikan kuantitatif, Kualitatif dan $R \& D$. Bandung: Alfabeta.

Sumiyati, W., Netriwati, \& Rakhmawati, R. (2018). Penggunaan Media Pembelajaran Geometri Berbasis Etnomatematika. Desimal: Jurnal Matematika, 1(1), 15-21.

Supriadi, N. (2015). Pembelajaran Geometri Berbasis Geogebra Sebagai Upaya Meningkatkan Kemampuan Komunikasi Matematis. Al-Jabar: Jurnal Pendidikan Matematika, 6(2), 99-109.

Trianto. (2004). Model Pembelajaran terpadu Konsep, Strategi Dan Implementasinya Dalam Kurikulum Tingkat Satuan Pendidikan. Jakarta: Bumi aksara. 